\title{
Hospitalizations due to primary care sensitive conditions in a population of older adults in the state of Rio Grande do Norte from 2008 to 2016
}

Katarina Márcia Rodrigues dos Santos' 1 (D Luciane Paula Batista Araújo de Oliveiral (D) Fábia Cheyenne Gomes de Morais Fernandes' (ID) Emelynne Gabrielly de Oliviera Santos ${ }^{2}$ (ID Isabelle Ribeiro Barbosa² ${ }^{2}$

\section{Abstract}

Objective: To identify hospitalizations to primary care sensitive conditions among older adults in the state of Rio Grande do Norte, Brazil. Method: An ecological study using information from the Hospitalization Information System of the Unified Health System was carried out. Mortality rate, permanence and costs resulting from hospitalization in the period from 2008 to 2016 were analyzed according to residence, age and sex. Results: The greatest proportions of hospitalizations were due to bacterial pneumonias and gastroenteritis. Illnesses that could be prevented by immunization had the longest average stay (on average 17 days); the highest admission rates were among men and for the over 80 age group, both in the period 2008-2010. In the period 2014-2016, hospitalizations for primary care sensitive conditions (or HPCSC) corresponded to $30.90 \%$ of all hospitalizations and $16.36 \%$ of the hospitalization expenses of the state. The average cost per HPCSC was R\$970.54 during the same three-year period. Conclusion: In Rio Grande do Norte, hospitalizations due to primary care sensitive conditions among older adults is decreasing, although it is still an important cause of hospitalization and public health spending.
Keywords: Primary Health Care. Hospitalization. Old Age Assistance. Length of Stay. Quality Indicators, Health Care.

\footnotetext{
Universidade Federal do Rio Grande do Norte, Faculdade de Ciências de Saúde do Trairi. Santa Cruz, $\mathrm{RN}$, Brasil.

2 Universidade Federal do Rio Grande do Norte, Centro de Ciências da Saúde, Programa de Pós-graduação em Saúde Coletiva. Natal, RN, Brasil.
}

Funding: This research was funded by the Coordination for the Improvement of Higher Education Personnel (CAPES). Process no 23038.013648/2018-51 - Master's program grant.

The authors declare that there are no conflicts of interest in relation to this study.

Correspondence

Emelynne Gabrielly de Oliveira Santos 


\section{INTRODUCTION}

Primary Care (PC) is one of the main entry points to the health system. In addition to access to services, this type of care is expected to have a resolutive capacity and be a mechanism for transforming realities through health promotion, prevention and protection ${ }^{1}$.

However, due to limitations in access to these services or the ineffectiveness of actions provided in primary care, users often require urgent and emergency care and/or hospitalizations for conditions that could be resolved at the primary level of care ${ }^{2}$. In this context, Hospitalizations for Primary Care Sensitive Conditions (HPCSC) represent avoidable hospitalizations or conditions sensitive to outpatient care. They are also indicators used to classify the resolutive capacity of PC, by registering hospitalizations for certain specific diseases, and which seek to evaluate and monitor the entry and efficiency of the treatment provided at this level of care, thus serving as a marker of quality ${ }^{3,4}$. It is understood that the greater the number of HPCSC, the lower the efficiency of PC will be, indicating failings in access to services or in the care itself ${ }^{5-7}$.

In this context, it is important to reflect on the aging process that the Brazilian population has undergone. This process is distinctive in developing countries due to the major demographic changes that have occurred in recent years. In Brazil, the growth of the older adult population, both in absolute and proportional terms, is increasingly significant, and reflected in social, health and social security demands ${ }^{8,9}$. According to the Brazilian Institute of Geography and Statistics (IBGE), the Brazilian older adult population in 2000 was $14,235,731$, while the projection for 2030 is 41,541,763 people $^{10}$.

Population aging is recognizably related to the increased prevalence of non-communicable chronic diseases, especially cardiovascular diseases. This situation generates greater demand for hospitalizations, drug treatments and patient rehabilitation, leading to increased spending on the secondary and tertiary care of the Unified Health System (SUS) ${ }^{11}$.
In Brazil, SUS hospitalization rates are high, and hospitalization costs are higher in people aged 60 years or older. The number of relapses in hospitalizations in this age group is also higher, contributing to $23 \%$ of the public expenditures of these hospitalizations among this population segment ${ }^{12}$. The main causes of reported HPCSC in the older adult population are heart failure, angina, lung disease, and cerebrovascular disease ${ }^{3,6}$.

The SUS evaluation process uses the Health Information System (HIS), which provides data that guide and/or generate new interventions and subsidies for strategic planning, improving management, whether in terms of control or in interventions focused on the needs encountered ${ }^{13}$.

The analysis of HPCSC, in turn, uses the SUS Hospital Information System (SUS/HIS), which has as its basic document the Hospitalization Authorization Form (HAF), which includes, among other information, patient diagnosis, demographics, location, date, length of stay and costs of hospitalization.

Given the above, the present study asked: What are the main causes of HPCSC in the state of Rio Grande do Norte (RN)? To understand this phenomenon, it is necessary to a consider ecological studies that analyze the behavior of these events over time, and which major population groups are affected. Such knowledge is of great importance for the planning and evaluation of PHC prevention and reorganization policies.

Thus, the aim of this study was to identify hospitalizations for Primary Care sensitive conditions among older adults in the state of Rio Grande do Norte, Brazil, from 2008 to 2016.

\section{METHOD}

An ecological study was carried out analyzing HPCSC, paid for by the SUS, in the state of Rio Grande do Norte, Brazil, from 2008 to 2016. The choice of the period allows a temporal analysis over nine years to be performed, in addition to reducing the possibility of data entry delays. 
For 2016, the hospital management network of Rio Grande do Norte consisted of 24 hospitals that provided 1,589 beds distributed among the eight health regions of the state as follows: eight in the Metropolitan region; three in the region of São José de Mipibu; three in the Mossoró region; three in the Caicó region; three in the Açu region; one in the João Câmara region; two in the Santa Cruz region and one in the Pau dos Ferros region ${ }^{14,15}$.
SUS/HIS data was collected from the website of the SUS Department of Informatics (DATASUS) and those on population from the IBGE website? The main diagnosis of hospitalizations registered in the SUS/HIS were HPCSC, according to code ICD-10, based on the list published in SUS/HIS Ordinance n ${ }^{\circ} 221 / 2008$ (Chart 1).

Chart 1. Diagnostic list of Primary Care Sensitive Conditions (PCSC) by group.

\begin{tabular}{|l|l|}
\hline List of Primary Care Sensitive Conditions (PCSC) & CID-10 \\
\hline Preventable immunization diseases and sensitive conditions & $\begin{array}{l}\text { A15 to A19, A33 to A37, A51 to A53, A95, B05, B06, } \\
\text { B16, B26, G00.0, B50 to B54 and I00 to I02 }\end{array}$ \\
\hline Infectious gastroenteritis and complications & A00 to A09 and E86 \\
\hline Anemia & D50 \\
\hline Nutritional deficiencies & E40 to E46 and E50 to E64 \\
\hline Ear, nose and throat infections & H66, J00 to J03, J06 and J31 \\
\hline Bacterial Pneumonia & J13, J14, J15.3, J15.4, J15.8, J15.9 and J18.1 \\
\hline Asthma & J45 and J46 \\
\hline Lung Diseases & J20 to J21, J40 to J44 and J47 \\
\hline Hypertension & I10 and I11 \\
\hline Angina & I20 \\
\hline Cardiac insufficiency & I50 and J81 \\
\hline Cerebrovascular diseases & I63 to I67, I69, G45 and G46 \\
\hline Diabetes mellitus & E10 to E14 \\
\hline Epilepsy & G40 and G41 \\
\hline Kidney and urinary tract infection & N10 to N12, N30, N34 and N39.0 \\
\hline Skin and subcutaneous tissue infection & A46, L01 to L04 and L08 \\
\hline Inflammatory disease in the female pelvic organs & N70 to N76 \\
\hline Gastrointestinal ulcer & K25 to K28, K92.0, K92.1 and K92.2 \\
\hline
\end{tabular}

Source: Ordinance $\mathrm{n}^{\circ}$ 221, dated 17 April 2008. 
Data collection was carried out in September 2018. The analyzes were performed from the SUS/ HIS HAF system, which consists of a summary of hospital discharges completed by SUS hospitals, to receive the hospitalizations carried out.

The HPCSC profile was assessed by age group (60-69 years; 70-79 years and over 80 years), by sex (male and female) and by the health region of the residence of the patients.

The HPCSC rate (total hospitalizations for HPCSC in Rio Grande do Norte, divided by the resident older adult population in 2012, multiplied by 1,000) was calculated; by HPCSC cause group (total HPCSC of the selected cause group, divided by the resident older adult population in the selected year (2008-2016), multiplied by 1,000); HPCSC by sex (number of HPCSC of resident patients according to sex, divided by population by sex, multiplied by 1,000 ) and by age group (number of HPCSC of patients in the age group considered, divided by total population in age group, multiplied by 1,000$)$. The proportion of HPCSC per health region was based on the number of HPCSC per region divided by the total HPCSC of the state over the same period, multiplied by 100 . For hospital mortality rate due to HPCSC, the number of deaths by HPCSC was divided by the resident population, multiplied by 1,000.

The total values of hospitalizations for all causes and the total value of HPCSC in reais ( $\mathrm{R} \$$ ) were calculated. The ratio of annual HPCSC spending (HPCSC spending of RN-resident patients divided by total hospitalization costs of $\mathrm{RN}$-resident patients) and the average amount spent per HPCSC (HPCSC costs of RN-resident patients divided by the number of HPCSC over the same period). To assess the changes that took place over the nine years of the series, we analyzed the percentage changes between the first and last quarter (subtracting the values recorded in the first quarter from those of the first quarter, divided by the value of the first quarter, multiplied by 100). All coefficients and proportions were analyzed over three-year periods: 2008-2010; 2011-2013; 2014-2016.

This study used secondary data available on the website of the Ministry of Health, without identifying the subjects, and was therefore exempt from consideration by a Research Ethics Committee, in accordance with Resolution No. 466/2012 of the National Health Council.

\section{RESULTS}

In the period 2008-2016, 105,543 hospitalizations for HPCSC occurred among older adults in the state of Rio Grande do Norte, totaling 810,456 days of hospitalization and a total cost of $\mathrm{R} \$ 86,785,404.58$. The groups of causes with the highest proportions of hospitalizations among the older adults were bacterial pneumonias (19.92\%); followed by infectious gastroenteritis and complications (17.52\%); cerebrovascular diseases (14.2\%); diabetes mellitus $(12.09 \%)$ and heart failure (11.92\%). Regarding the average length of hospitalization among such patients, the groups of causes with the highest rates were preventable diseases due to immunization and sensitive conditions (17 days on average), diabetes mellitus $(10.72 \%)$ and skin infection. and subcutaneous tissue (10.05 days). Regarding the average cost, the groups of causes with the highest values were preventable diseases due to immunization and sensitive conditions (1,946.41 reais/hospitalization), heart failure (1,677.61 reais/ hospitalization), cerebrovascular diseases (1,013.50 reais/hospitalization). hospitalization) and bacterial pneumonias (922.51 reais/hospitalization) (Table 1). 


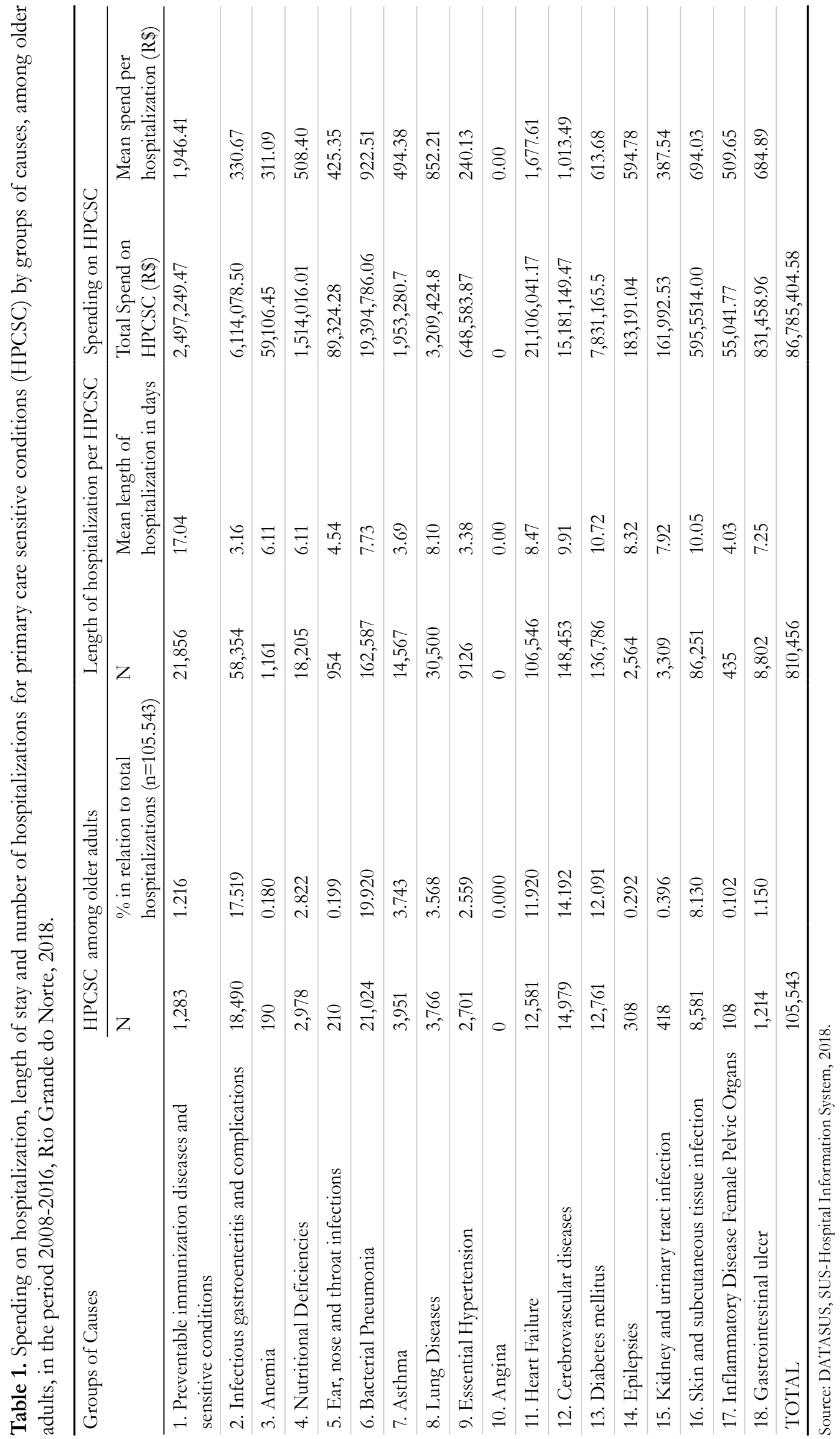


In the group of preventable diseases by immunization and sensitive conditions, respiratory $(\mathrm{n}=534)$ and pulmonary $(\mathrm{n}=511)$ tuberculosis together represented over $81 \%$; while diarrhea and gastroenteritis $(n=8,872)$, other infectious intestinal diseases $(n=8,580)$ and volume depletion $(n=994)$ together accounted for $99 \%$ of HPCSC cases for the infectious gastroenteritis and complications group. The group of nutritional deficiencies was represented entirely by malnutrition $(n=2,976)$.

As shown in Table 2, the highest proportion of HPCSC occurred in the metropolitan region of the state $(24.70 \%)$. The highest HPCSC coefficients were recorded in the region of Pau dos Ferros (557.33 hospitalizations/1,000 inhabitants) and Caicó (513.07 hospitalizations/1,000 inhabitants).

Table 3 shows the results of the HPCSC coefficients, the costs and the average length of stay per cause over three trienniums. The rate of HPCSC decreased, with a rate of 41.18 hospitalizations/1,000 inhabitants in the 2008-2010 triennium and a rate of 28.12 hospitalizations/1,000 inhabitants in the 2014-2016 triennium. The highest rates were observed for men, although rates decreased over time for both sexes in the same proportion. In relation to age group, older adults aged over 80 had the highest rates (89.65 hospitalizations/1,000 inhabitants) in the 2008-2010 triennium, although this age group exhibited the greatest reduction in HPCSC rates over the three trienniums. The 70-79 years age group presented the smallest reduction in the analyzed period (reduction of $5 \%$ between 2008 and 2016). Although PHCSC hospitalization rates decreased over the years, the average length of stay as well as the average amount spent on each hospitalization increased by $28.94 \%$ and $39.74 \%$, respectively. The average length of stay per HPCSC was 8.92 days and the average amount spent per HPCSC was 970.54 reais, considering the three-year period 2014-2016.

Figure 1 shows that as of 2011, the rate of HPCSC decreased from 42.64 hospitalizations/1,000 inhabitants in 2009 to 25 hospitalizations/1,000 inhabitants in 2016. The highest hospital mortality rate due to HPCSC was recorded in 2009 (4.65 deaths/1,000 inhabitants) and the lowest rate was in 2016 (3.38 deaths/1,000 inhabitants).

Table 2. Rate of Hospitalizations for Primary Care Sensitive Conditions (HPCSC) and proportion of HPCSC among older adults by health region 2008-2016, Rio Grande do Norte, Brazil.

\begin{tabular}{|c|c|c|c|c|}
\hline RN Health Region & $\begin{array}{l}\mathrm{N}^{\circ} \text { of HPCSC- } \\
\text { Older Adults }\end{array}$ & Proportion (\%) & $\begin{array}{l}\text { Population } \\
\text { (Older Adults) }\end{array}$ & $\begin{array}{l}\text { Rate of HPCSC-Older adults } \\
\text { by health region (1000 inhab) }\end{array}$ \\
\hline São José de Mipibu & 8,016 & 7.52 & 37,247 & 215.212 \\
\hline Mossoró & 15,554 & 14.60 & 43,636 & 356.449 \\
\hline João Câmara & 7,944 & 7.45 & 33,288 & 238.645 \\
\hline Caicó & 19,823 & 18.60 & 38,637 & 513.057 \\
\hline Santa Cruz & 6,831 & 6.41 & 23,067 & 296.137 \\
\hline Pau dos Ferros & 17,786 & 16.69 & 31,913 & 557.328 \\
\hline Metropolitan Region & 26,319 & 24.70 & 115,384 & 228.099 \\
\hline Açu & 4,247 & 3.98 & 15,088 & 281.482 \\
\hline
\end{tabular}

Source: DATASUS, SUS Hospital Information System, 2018. 
Table 3. Analysis of rates of Hospitalizations for Primary Care Sensitive Conditions (HPCSC), HPCSC spending (R\$) and length of stay for such causes in older adults 2008-2016, Rio Grande do Norte, Brazil.

\begin{tabular}{|c|c|c|c|c|}
\hline \multirow{2}{*}{ Variables } & \multicolumn{3}{|c|}{ Triennium } & \multirow{2}{*}{ Variation* } \\
\hline & $2008-2010$ & 2011-2013 & 2014-2016 & \\
\hline HPCSC-Older Adults RN Rate & 41.18 & 35.58 & 28.12 & -31.71 \\
\hline \multicolumn{5}{|l|}{ HPCSC-Older Adults Rate } \\
\hline Women & 38.61 & 33.02 & 26.3 & -31.88 \\
\hline Men & 44.53 & 38.96 & 30.53 & -31.43 \\
\hline \multicolumn{5}{|l|}{ HPCSC (years) } \\
\hline $60-69$ & 23.71 & 20.18 & 15.6 & -34.2 \\
\hline $70-79$ & 46.16 & 39.28 & 43.47 & -5.83 \\
\hline$>80$ & 89.65 & 81.79 & 67.49 & -24.72 \\
\hline $\mathrm{N}^{o}$ HPCSC-Older Adults & 38,182 & 36,116 & 31,247 & -18.16 \\
\hline $\mathrm{N}^{\mathrm{o}}$ hospitalizations for all causes & 94,620 & 101,710 & 101,125 & 6.87 \\
\hline Proportion HPCSC/General Hospitalization & $40.35 \%$ & $35.51 \%$ & $30.90 \%$ & -23.43 \\
\hline Length of stay (days) HPCSC-Older Adults & 264,257 & 267,377 & 278,847 & 5.52 \\
\hline Mean length of stay (days) HPCSC-Older Adults & 6.92 days & 7.40 days & 8.92 days & 28.94 \\
\hline Cost of HPCSC-Older Adults & $26,519,066.98$ & $29,941,625.70$ & $30, .326,373.23$ & 14.36 \\
\hline Cost of hospitalizations for all causes & $113,455,387.00$ & $151,089,703.50$ & $185,394,652.80$ & 63.41 \\
\hline $\begin{array}{l}\text { Proportion spent on HPCSC-older adults/ } \\
\text { general hospitalizations }\end{array}$ & $23.37 \%$ & $19.82 \%$ & $16.36 \%$ & -30.02 \\
\hline Mean cost of HPCSC-Older Adults (em R\$) & 694.54 & 829.04 & 970.54 & 39.74 \\
\hline
\end{tabular}

Source: DATASUS, SUS Hospital Information System, 2017.

* Variation in value between $3 \mathrm{rd}$ and 1 st triennium.

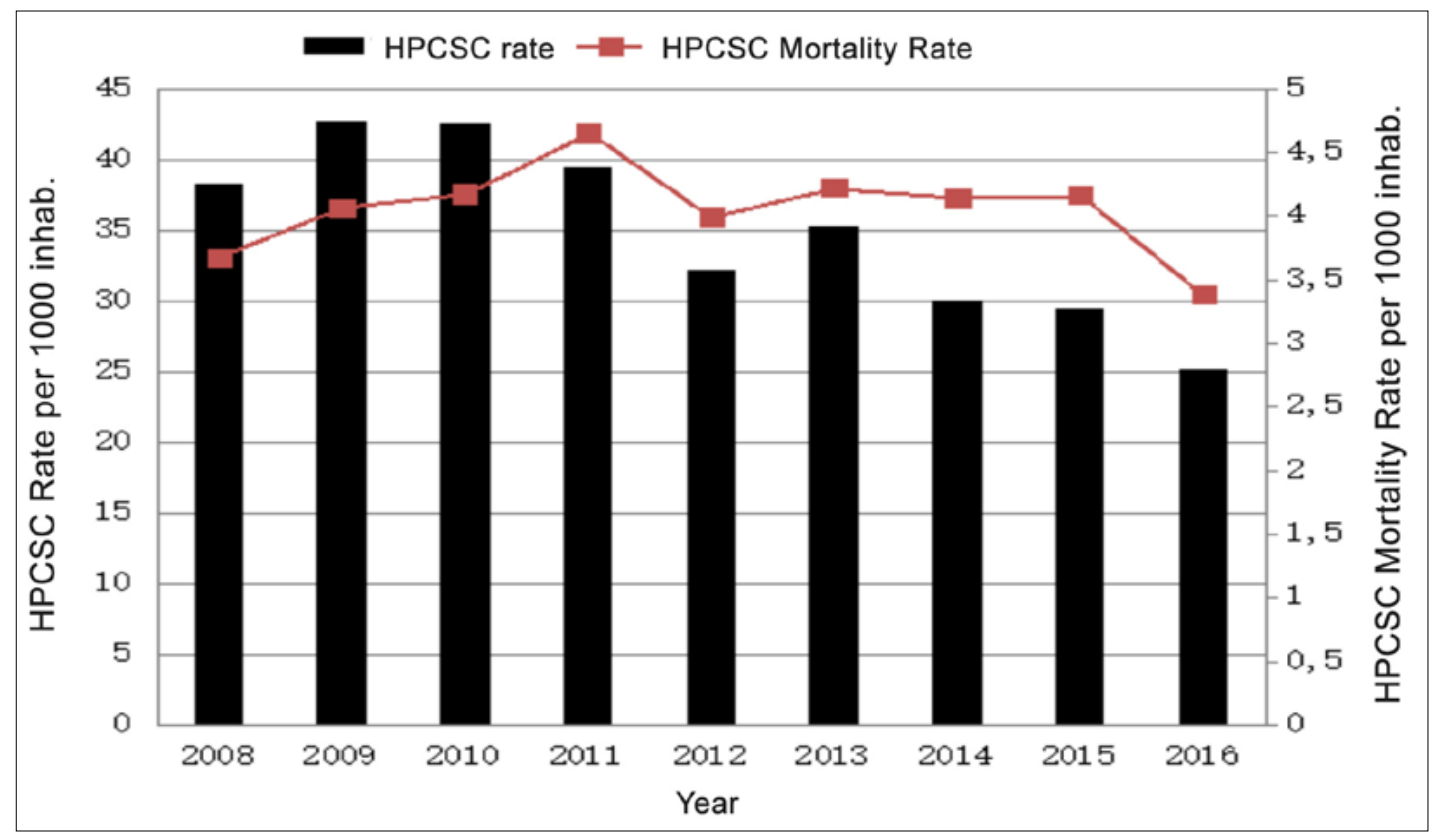

Source: DATASUS, Hospitalization System, 2018.

Figure 1. Temporal analysis of the hospitalization rate and mortality due to Hospitalizations for Primary Care Sensitive Conditions (HPCSC), in the period 2008-2016, in the state of Rio Grande do Norte, Brazil. 


\section{DISCUSSION}

The present study described the scenario for Rio Grande do Norte and its health regions in relation to HPCSC for the older adult population, noting a reduction in hospitalization rates for such causes in recent years. From the characterization of the hospitalizations, it was observed that the highest rates of HPCSC affected men, long-lived older adults and the health region of Pau dos Ferros and Caicó. Additionally, the costs of such hospitalizations corresponded to a considerable percentage of the amount spent on hospitalizations in the state. As HPCSC may reflect a disorganized supply or failings in resolutive capacity and access in primary care, the results of this study are important for further analysis of this stage of the care network in this region.

The occurrence of HPCSC in older adults, in addition to other factors, may be related to the most common access limitations in this population, such as mobility and transportation difficulties and a high degree of dependence ${ }^{15}$. With the increase in life expectancy and population aging, the health problems that most affect this population are chronic diseases and/or long-term diseases, requiring more costly actions and the use of more complex technologies. The older population makes the greatest use of health services and rate index has been increasing concomitantly with the demographic profile ${ }^{16,17}$.

In a survey conducted in the city of Londrina (Paraná), the older adult population $(9.3 \%$ of the population) corresponded to $20.2 \%$ of hospitalizations, $22.1 \%$ of days of hospital stay and $29.1 \%$ of SUS hospital costs ${ }^{18}$. In 2007, in the municipality of Canoas (Rio Grande do Sul), individuals aged 60 or older had a higher prevalence of hospitalization (17.2\%), with a 4.96 times greater probability of being hospitalized than the age group used as reference (14-19 years) ${ }^{19}$.

Literature $^{20}$ reports a seven times greater risk of hospitalization due to a PHCSC among older adults. The discussions describe these individuals as physically and financially vulnerable, and having little understanding of primary care practices. These characteristics may represent the under-utilization of primary care in a preventive manner, which in turn may result in avoidable hospitalizations, with increased morbidity and a direct cost impact on the public health system ${ }^{21}$.

In the present study, the most frequent diagnoses found in HPCSC among older adults were for bacterial pneumonia, infectious gastroenteritis and complications, and diabetes mellitus. Circulatory system diseases accounted for around 25\% of hospitalizations, which is similar to the results of a study that analyzed the HPCSC of older adults in the state of Rio de Janeiro ${ }^{6}$, and found that $49.0 \%$ of hospitalizations are due to these causes. In addition, a study that analyzed HPCSC in older adults in Santa Catarina found that these causes represented 23.76\% of total hospitalizations ${ }^{22}$. Other studies analyzing HPCSC in the adult population also corroborate these findings $\mathrm{s}^{12,16,23}$.

Immunopreventable diseases were also a notable cause of hospitalization in the present study. This finding is corroborated by a study that analyzed HPCSC in Brazilian regions and showed that, in the northeast of the country, HPCSC for preventable diseases by immunization and preventable conditions are the most prevalent ${ }^{24}$. For diseases prevented by immunization, as suggested by the National Immunization Program, vaccination is a highly effective preventive resource, available in primary care and carried out by nurses, both in terms of operational issues in vaccine rooms, and in the monitoring of the different stages of this process ${ }^{25}$.

The hospitalization coefficient for gastroenteritis in the present study was notable. This finding points to possible failures in preventive and curative care in the sphere of primary care, which should be effective and resolutive against the first manifestations of this event, especially in this age group. A study conducted in the northeastern states of Brazil showed that oral rehydration serum, considered a minimal technology and low cost intervention, was highly effective in preventing deaths from gastroenteritis ${ }^{26,27}$.

Another relevant finding is the registration of congenital syphilis among the causes of HPCSC. Sexually transmitted infections (STI) are increasingly common in this population, and according to a study by Dornelas et al. ${ }^{28}$, an increase in the longevity of the sex life occurs in parallel with an increase 
in life expectancy, whether due to technological advances (such as the use of impotence and/or hormone replacement pills), combined with greater predisposition due to physiological changes, increasing the risk of STI.

The present study observed a decline in HPCSC rates over the study period, a fact corroborated by a study that conducted a descriptive review of the results of Brazilian academic production on conditions sensitive to primary care. This study showed that, despite having high rates in some isolated states and/ or municipalities, there is a tendency for HPCSC to stabilize and decline in different Brazilian regions. ${ }^{29}$. The study that analyzed the HPCSC of older adults in Brazil, from 2003 to 2012, found that the northeast region has the lowest hospitalization rate for these causes, and that in Brazil, there was a reduction of $17.64 \%$ in HPCSC in the period considered ${ }^{30}$. This tendency to reduce or stabilize hospitalizations may be justified by the transfer of procedures previously performed only through hospitalization, to outpatient and hospital day care. On the other hand, it may mean the improved access to and effectiveness of $\mathrm{PHC}^{3}$.

Continuing with this theme, the implementation of the Family Health Strategy (FHS) in Brazil has resulted in a significant expansion of coverage in the last decade, with different rates between regions and depending on the population size of municipal regions. Administrative data from the Basic Care Department (BCD) of the Health Care Department of the Ministry of Health revealed out that in 2012, $95 \%$ of Brazilian municipal regions had a total of 33,404 FHS teams deployed, with potential to reach $55 \%$ of the population. However, there are important differences in coverage, access, and provision of care in Basic Health Units (BHU) in municipal regions, partly due to management structures and social inequalities in the country, with significant effects on inequities in access to and the use of health services ${ }^{31}$.

HPCSC rates in Rio Grande do Norte, when compared with other areas of Brazil, are considered low. In a study conducted in the Federal District, older adults aged 70 to 79 years, for example, had significant HPCSC coefficients (60 hospitalizations/1,000 inhabitants for women and 80 hospitalizations/1,000 inhabitants for men $)^{26}$. The continued higher proportions of HPCSC in older adults in the south and southeast may be related to the fact that these regions have the highest proportion of older adults and the highest rate of aging in the country ${ }^{30}$.

Regarding the amount spent on HPCSC, the data from the present study were consistent with the results of a national study that showed a reduction in spending on HPCSC from 2000 to 2013. This study showed that in 2013, the costs of HPCSC were $17.4 \%$ of the spending of the public health system on all hospitalizations ${ }^{23}$, similar to the findings of the present study.

It should be noted that there are limitations on the use of hospitalizations for conditions sensitive to primary care. A decrease in hospitalization rates for these causes indicates only possible improvements in primary care. The other numerous factors that influence hospitalization rates are not easily measured and adjusted/controlled. The analysis of these hospitalizations depends, among other things, on administrative data (such as hospitalization authorizations), and this can accentuate the problems present in these databases. The use of HPCSC in research requires careful analysis of hospital data sources themselves ${ }^{32}$. Nevertheless, the SUS/HIS is used in several studies and its results have been consistent and coherent with reality.

\section{CONCLUSION}

The present study allowed us to identify the evolution of hospitalizations for primary care sensitive conditions in older adults (HPCSC) in the state of Rio Grande do Norte, considering the differential roles of age, sex and diagnosis of hospitalization during the analyzed period, especially in terms of the reduction in the proportion of these expenses in the total spending on hospitalizations of the Unified Health System.

In addition, a progressive reduction in HPCSC was revealed, which may be related to Primary Care and its considerable impacts on hospital morbidity, contributing to a healthy aging and higher life expectancy, as HPCSC are indicators of quality of care, allowing weaknesses to be identified, alerting managers to focuses of needs for intervention. 
Finally, the importance of subsidizing policies that strengthen primary care in Brazil and which include programs focused on the social determinants of health is emphasized, as well as the need for the constant monitoring of indicators related to HPCSC, including the spending involved in these procedures.

Edited by: Ana Carolina Lima Cavaletti

\section{REFERENCES}

1. Campos RTO, Ferrer AL, Gama CAP, Campos GWS, Trapé TL, Dantas DV. Avaliação da qualidade do acesso na atenção primária de uma grande cidade brasileira na perspectiva dos usuários. Saúde Debate [Internet]. 2014 [acesso em 29 set. 2018];38(n. spe.):252-64. Disponível em: http://www.scielo. $\mathrm{br} /$ scielo.php?script $=$ sci_arttext\&pid $=$ S0103$11042014000600252 \& \operatorname{lng}=$ en\&nrm=iso\&tlng=pt

2. Rissardo LJ, Rego AS, Scolari GAS, Radovanovic CAT, Decesaro MN, Carreira L. Idosos atendidos em unidade de pronto-atendimento por condições sensíveis a Atenção Primaria a Saúde. Rev Min Enferm [Internet]. 2016 [acesso em 29 set. 2018];20:e971 [7 p.]. Disponível em: http://www. dx.doi.org/10.5935/1415-2762.20160041

3. Sousa NP, Rehem TCMSB, Santos WS, Santos CE. Internações sensíveis à atenção primária à saúde em hospital regional do Distrito Federal. Rev Bras Enferm [Internet]. 2016 [acesso em 30 set. 2018];69(1):118-25. Disponível em: http://dx.doi. org/10.1590/0034-7167.2016690116i

4. Souza LL, Costa JSD. Internações por condições sensíveis à atenção primária nas coordenadorias de saúde no RS. Rev Saúde Pública [Internet]. 2011 [acesso em 01 out 2018];45(4):765-72. Disponível em: http://www.scielo.br/scielo.php?script $=$ sci_ arttext\&pid=S0034-89102011000400017

5. Marques AP. Análise das causas de internação de idosos segundo a classificação de Condições Sensíveis à Atenção Primária: estudo da evolução temporal no Estado do Rio de Janeiro [dissertação na Internet]. Rio de Janeiro: Fiocruz; 2012 [acesso em 01 out. 2018]. Disponível em: https://www.arca.fiocruz.br/ handle/icict $/ 24600$

6. Marques AP, Montilla DER, Almeida WS, Andrade LTC. Internação de idosos por condições sensíveis à atenção primária à saúde. Rev Saúde Pública [Internet]. 2014 [acesso em 02 out 2018];48(5):817-26. Disponível em: http://www.scielo.br/scielo.php?script=sci_ arttext\&pid=S0034-89102014000500817

7. BRASIL. Portaria n. 221, de 17 de abril de 2008. Publica em forma do anexo a lista brasileira de internações por condições sensíveis à Atenção Primária. Diário Oficial da União. Brasília, DF. 21 set. 2008. Disponível em: http://bvsms.saude.gov.br/ bvs/saudelegis/sas/2008/prt0221_17_04_2008.html

8. Oliveira ATRD. Envelhecimento populacional e políticas públicas: desafios para o Brasil no século XXI. Espaço Econ [Internet] 2016 [acesso em 2019 ago 01];4(8):2-21.

9. Miranda GMD, Mendes ACG, Silva ALA. O envelhecimento populacional brasileiro: desafios e consequências sociais atuais e futuras. Rev Bras Geriatr Gerontol [Internet]. 2016 [acesso em 02 out 2018];19(3):507-19. Disponível em: http://dx.doi. org/10.1590/1809-98232016019.150140

10. Instituto Brasileiro de Geografia e Estatística. Coordenação de População e Indicadores Sociais. Síntese de indicadores sociais: uma análise das condições de vida da população brasileira: 2016. Rio de Janeiro: IBGE; 2016.

11. Kernkamp CL, Costa CKF, Massuda EM, Silva ES, Yamaguchi MU, Bernuci MP. Perfil de morbidade e gastos hospitalares com idosos no Paraná, Brasil, entre 2008 e 2012. Cad Saúde Pública [Internet]. 2016 [acesso em 05 out 2018];32(7):e00044115 [14 p.]. Disponível em: http://www.scielo.br/pdf/csp/ v32n7/1678-4464-csp-32-07-e00044115.pdf

12. Muraro CF, Gigante LP, Nedel FB, Carvalho TGML, Domenech SC, Gevaerd MS. Estratégia saúde da família e as internações por condições sensíveis a atenção primária nos idosos. Rev Baiana Saúde Pública [Internet]. 2013 [acesso em 07 out. 2018];37(1):20-33. Disponível em: http://files.bvs.br/ upload/S/0100-0233/2013/v37n1/a3813.pdf

13. Rede Interagencial de Informação para a Saúde. Indicadores básicos para a saúde no Brasil: conceitos e aplicações. 2. ed. Brasília, DF: Organização PanAmericana da Saúde; 2008. 
14. Instituto Brasileiro de Geografia e Estatística. Brasil/ Rio Grande do Norte. Rio de Janeiro : IBGE; 2018 [acesso em 29 set. 2018]. Disponível em: https:// cidades.ibge.gov.br/brasil/rn/panorama

15. Natal. Secretaria de Estado da Saúde Pública. Plano Estadual de Saúde PAS 2016-2019 [Internet]. Natal: SESAP; 2016 [acesso em 29 set 2018]. Disponível em: http://adcon.rn.gov.br/ACERVO/sesap/DOC/ DOC000000000142450.PDF

16. Ferreira JBB, Borges MJG, Santos LL, Forster AC. Internações por condições sensíveis à atenção primária à saúde em uma região de saúde paulista, 2008 a 2010. Epidemiol Serv Saúde [Internet]. 2014 [acesso em 03 out 2018];23(1):45-56. Disponível em: http://dx.doi.org/10.5123/S1679-49742014000100005

17. Paskulin LMG, Valer DB, Vianna LAC. Utilização e acesso de idosos a serviços de atenção básica em Porto Alegre (RS, Brasil). Ciênc Saúde Colet [Internet]. 2011 [acesso em 03 out. 2018];16(6):293544. Disponível em: http://dx.doi.org/10.1590/S141381232011000600031

18. Martin GB, Cordoni Jr L, Bastos YGL, Silva PV. Assistência hospitalar à população idosa em cidade do sul do Brasil. Epidemiol Serv Saúde [Internet]. 2006 [acesso em 04 out. 2018];15(1):59-65. Disponível em: http://dx.doi.org/10.5123/S1679-49742006000100005

19. Garbinato LR, Beria JU, Figueiredo AC, Raymann B, Gigante LP, Palazzo LS, et al. Prevalência de internação hospitalar e fatores associados: um estudo de base populacional em um centro urbano no Sul do Brasil. Cad Saúde Pública [Internet]. 2007 [acesso em 06 out 2018];23(1):217-24. Disponível em: http:// dx.doi.org/10.1590/S0102-311X2007000100023

20. Dourado I, Oliveira VB, Aquino R, Bonolo P, LimaCosta MF, Medina MG, et al. Trends in primary health care-sensitive conditions in Brazil: the role of the Family Health Program (Project ICSAPBrazil). Med Care [Internet]. 2011 [acesso em 12 out. 2018];49(6):577-84. Disponível em: https://www.ncbi. nlm.nih.gov/pubmed/21430576

21. Cardoso CS, Pádua CM, Rodrigues Júnior AA, Guimarães DA, Carvalho SF, Valentin RF, et al. Contribuição das internações por condições sensíveis à atenção primária no perfil das admissões pelo sistema público de saúde. Rev Panam Salud Pública. 2013;34(4):227-34.

22. Probst GHS, Dynkoski MA, Busato MA. Internação por condições sensíveis à Atenção Primária em idosos de Santa Catarina: o caso da insuficiência cardíaca. In: $2^{\circ}$ Congresso Brasileiro Interdisciplinar de Promoção da Saúde; 18 a 20 outubro 2016, Santa Cruz do Sul. Santa Cruz do Sul: Universidade de Santa Cruz do Sul; 2016.
23. Souza DK, Peixoto SV. Estudo descritivo da evolução dos gastos com internações hospitalares por condições sensíveis à atenção primária no Brasil, 2000-

2013. Epidemiol Serv Saúde [Internet]. 2017 [acesso em 15 out 2018];26(2):285-94. Disponível em: http://www. scielo.br/scielo.php?script=sci_arttext\&pid=S223796222017000200285\&lng=en\&nrm=iso\&tlng=pt

24. Pereira FJR, Silva CC, Lima Neto AE. Perfil das internações por condições sensíveis à atenção primária subsidiando ações de saúde nas regiões brasileiras. Saúde Debate [Internet]. 2015 [acesso em 18 out 2018];40(107):1008-17. Disponível em: http://www. scielo.br/scielo.php?script $=$ sci_arttext\&pid=S010311042015000401008\&lng=pt\&tlng=pt

25. Luciano TV, Dias JA. Internações por condições sensíveis a atenção primária em município da região Norte do Espírito Santo. Rev Bras Pesqui Saúde. 2016;17(3):23-32.

26. Junqueira RMP, Duarte EC. Internações hospitalares por causas sensíveis à atenção primária no Distrito Federal, 2008. Rev Saúde Pública [Internet]. 2012 [acesso em 20 out. 2018];46(5):761-8. Disponível em: http://www. scielo.br/scielo.php?script $=$ sci_arttext\&pid $=$ S0034$89102012000500001 \& \operatorname{lng}=$ pt\&tlng $=$ pt

27. Victora CG, Barros FC, Tomasi E, Ferreira FS, MacAuliffe J, Silva AC, et al. A saúde das crianças dos estados do Ceará, Rio Grande do Norte e Sergipe, Brasil: descrição de uma metodologia para diagnósticos comunitários. Rev Saude Publica [Internet]. 1991 [acesso em 02 ago. 2019];25(3):21825. Disponível em: http://www.scielo.br/ scielo.php? script $=$ sci_abstract\&pid $=$ S003489101991000300009\&lng=pt\&nrm=iso\&tlng=en

28. Dornelas Neto J, Nakamura AS, Cortez LER, Yamaguchi MU. Doenças sexualmente transmissíveis em idosos: uma revisão sistemática. Ciênc Saúde Colet [Internet]. 2015 [acesso em 22 out. 2018];20(12):3853-64. Disponível em: http://www.scielo.br/scielo.php?script=sci_ arttext\&pid $=$ S1413-81232015001203853

29. Pereira FJR, Silva CC, Lima Neto AE. Condições Sensíveis à Atenção Primária: uma revisão descritiva dos resultados da produção acadêmica brasileira. Saúde Debate [Internet]. 2014 [acesso em 24 out. 2018];38(n.spe):331-42. Disponível em: http://www. scielo.br/scielo.php?script $=$ sci_arttext\&pid $=$ S0103$11042014000600331 \& \operatorname{lng}=$ en\& $\mathrm{nrm}=\mathrm{i}$ so\&tlng $=\mathrm{pt}$

30. Amorim DNP, Chiarello MD, Vianna LG, Moraes CF, Vilaça KHC. Internações por Condições Sensíveis à Atenção Primária de Idosos no Brasil, 2003 a 2012. Rev Enferm UFPE on line [Internet]. 2017 [acesso em 29 out. 2018];11(2):576-83. Disponível em: file://C:/ Users/Cliente/Downloads/11976-28968-1-PB.pdf 
31. Malta DC, Santos MAS, Stopa SR, Vieira JEB, Melo EA, Reis AAC. A Cobertura da Estratégia de Saúde da Família (ESF) no Brasil, segundo a Pesquisa Nacional de Saúde, 2013. Ciênc Saúde Colet [Internet]. 2016 [acesso em 29 out. 2018];21(2):327-38. Disponível em: http://www.scielo.br/scielo.php?script=sci_ arttext\&pid=S1413-81232016000200327
32. Alfradique ME, Bonolo PF, Dourado I, Lima-Costa MF, Macinko J, Mendonça CS, et al. Internações por condições sensíveis à atenção primária: a construção da lista brasileira como ferramenta para medir o desempenho do sistema de saúde (Projeto ICSAP Brasil). Cad Saúde Pública. 2009;25(6):1337-49. 